\title{
Scholarship and security policy: a review of recent literature
}

\author{
HAROLD KARAN JACOBSON1
}

\author{
University of Michigan
}

\section{I}

Academic awareness of and interest in security policy has markedly increased in recent years. Partially, this is the result of the United States being thrust into a position of world leadership, where it has been forced as never before to rely on military techniques. The revolutionary developments in military technology have been an equally important stimulus. Anything that accounted for roughly two-thirds of the federal budget, as military matters now do, would be certain to attract academic attention. The vastly increased destructive power and speed of new weapons made military questions even more important and their examination by scholars more urgent. Had the only question been that of adjusting American thinking to the United States new military responsibilities, the task of scholarship would not have been exceedingly difficult. Even though American scholars rarely considered security policy prior to the conclusion of the second World War, with the literature from other states there were ample sources, and a number of concepts were well established. However, the actual situation has been infinitely more complex; developments in

1 The author is the World Affairs Center Fellow for $1959-60$ and is on leave of absence from his regular position. weapons technology have cast doubt on all earlier concepts, some may continue to be relevant, but all are in question until the contrary is proved. The task of scholarship in the field of security policy has been immense. The challenge has produced a voluminous literature, some imaginative and creative thought, and the beginnings of new doctrines for the employment of military techniques in world politics when and if necessary. This review attempts critically to evaluate some of the most prominent works in this burgeoning literature, to consider their policy impact (or lack thereof), and to suggest areas where further research might prove fruitful.

II

For analysis the seven books reviewed may be divided into four categories. Two, Henry Kissinger's Nuclear Weapons and Foreign Policy (6) and Robert Osgood's Limited War (7), are in a sense narrow in focus and purpose. Both books urge that Americans develop more diversified and sophisticated ideas concerning the use of force, arguing particularly for acceptance of the concept of limited war. Kissinger starts with the assumption that, for the present, renunciation of the use of force would "place the international order at the mercy of its most ruthless or its most irresponsible 
member" (pp. 4-5). If the United States were to renounce or greatly inhibit its ability to use force, in his view, a vacuum would be created into which the Soviet Union would move with impunity. The problem in the nuclear age is to find a method of employing force which does not involve intolerable destruction. Kissinger argues that traditional American strategic doctrine, dominated, he feels, by the concept of all-out war, is inappropriate because of the nuclear holocaust it would invoke. He argues that a concept of limited nuclear war would be more appropriate for all but the gravest crises. His book is forcefully written; it has been widely read and has rightly gained great acclaim.

Mr. Osgood's Limited War, although it makes greater use of historical material, has the same policy orientation, raises virtually identical questions, and suggests a roughly similar answer-the concept of limited war. Osgood shows greater awareness of the military, psychological, and other problems involved in the tactical use of nuclear weapons, but he nevertheless concludes that they should be so used (pp. 251 ff.). His book contains a deeper analysis of American attitudes toward war (chap. ii) and, perhaps for this reason, is less optimistic about the willingness of Americans to adopt the recommended strategy. Kissinger and Osgood both think that war can remain limited in scope and technique only if the objectives pursued are limited and narrowly defined, and both men are strongly influenced by their perception of war in the eighteenth and nineteenth centuries and of the Korean War. Each book contains an analysis of the logical implications of limited war and an attempt to apply these to the United States global policies.

American Military Policy (3) by Edgar S. Furniss, Jr., and Military Policy and National Security (5) by William W. Kaufmann are alike in their broad orientation and in being anthologies. Both books cover most phases of security policy from economic mobilization and civil defense to coalition strategy. The former, designed for text use, is the more complete, although this necessitated the inclusion of some less than topquality selections. This volume's greatest contribution is making readily available some of the most important articles of the past decade in this field. Bernard Brodie's "Strategy as a Science" remains one of the best statements of the need for scholarly analysis of security policy; it should be the starting point for all students in this field. Robert Cutler's description of the National Security Council, Carl Kaysen's analysis of the United States vulnerability to enemy attack, Clark W. Tinch's study of the quasiwar between Japan and the U.S.S.R. from 1937 through 1939, and Rear Admiral Sir Anthony W. Buzzard's plea for a policy of graduated deterrence are all articles of lasting importance which should be widely read. There is also much to be gained from reading the late John Foster Dulles' "massive retaliation" speech which is reprinted in Mr. Furniss' book. Present United States defense policies still in large measure follow the pattern Mr. Dulles articulated, the defense budget still giving primary emphasis to high-yield nuclear weapons.

Military Policy and National Security contains eight essays, and, though somewhat uneven, all are provocative. The essays have unity as all attempt to explore the implications of nuclear weapons for international affairs. Mr. Kaufmann's own essays on deterence and limited war are among the best analyses of these topics. The first of these explores the logical implications of Dulles' speech and the policy advocated therein. In Kaufmann's view, if the threat of "massive retaliation" is to provide a credible deterrent to aggressive enemy action, it must be 
reserved for the most serious contingencies, those in which we would truly be willing to incur the risks involved in carrying it out, and not used in every instance, as Dulles appeared to imply (pp. $26 \mathrm{ff}$.). He advocates, in his second essay, meeting other menaces to American security interests with limited war. Kaufmann forthrightly points out the economic and other costs involved in developing the necessarily diversified capabilities this doctrine demands, and he also bluntly states that "limited war cannot be a means of bringing about a radical alteration in the distribution of power" (p. 127). Throughout this volume there is a sense of the tentativeness of our knowledge about the meaning of nuclear weapons and the future course of war-Klaus Knorr particularly emphasizes this in his essay on war potentialand, if there is a general theme, it is that because of this tentativeness the United States should pursue broadly based and flexible security policies.

Assumptions about the Soviet Union, its military policies, and future actions are crucial for any analysis in this field. The previously mentioned works deal with these questions either implicitly (Furniss and Kaufmann) or explicitly in separate sections (Kissinger and Osgood). In addition, two books, Raymond L. Garthoff's Soviet Strategy in the Nuclear Age (4) and Herbert S. Dinerstein's War and the Soviet Union (2), are exclusively devoted to such problems. Of the two, Mr. Garthoff's is broader; it describes how Soviet officers are involved in the governmental structure and process and the nature and composition of Soviet military forces. It also analyzes the recent evolution of Soviet strategic doctrine. Since the death of Joseph Stalin, military strength in the governmental process has increased, and officers now enjoy greater freedom from political control. Further, there has also been a significant revision of military doc- trine. The new developments in weapons technology have been integrated into Soviet strategic thought, but Garthoff thinks that the strategic concept continues to be "founded on the belief that the primary object of military operations is the destruction of hostile military forces, and not the annihilation of the economic and population resources of the enemy" (p. 71). The Soviet elite has not chosen to place primary emphasis on strategic bombing, nor has the air force been made the dominant arm (as an illustration, no air-force officer can attain the highest military rank [p. 54]). Garthoff believes that, even though the Soviet Union has become doctrinally and otherwise prepared for general nuclear war, it is not committed to this form of warfare. It has maintained a broadly diversified capability. Although there appears to have been no explicit discussion advocating limited war in the Soviet Union, the U.S.S.R. has engaged in such contests in the past and is capable of doing so in the future. Garthoff thinks that it is "improbable" that the U.S.S.R. "would initiate the use of nuclear weapons in a local war" (p. 115), but, if the West introduced these weapons, the Soviets would most likely reply in kind. In such a situation he feels that, despite pronouncements to the contrary, the Soviet Union might well agree in practice to limitations on the tactical use of nuclear weapons (pp. $110 \mathrm{ff}$.). The author's main theme is that the Soviet Union's military preparation will allow it flexibility in strategic decision so that in any contingency it can "select the most advantageous and least costly of alternatives" ( $p$. 249).

War and the Soviet Union concentrates more narrowly on the evolution of high-level political-military strategic doctrine. One of Mr. Dinerstein's main theses is that "readiness to strike a pre-emptive blow became, early in 1955, a principal aim of official 
Soviet policy" (p. 188). A "pre-emptive" blow is defined as a strike designed to forestall an imminent enemy attack. Dinerstein thinks that Soviet leaders, in considering the implications of nuclear weapons, have radically revised their estimate of the significance of surprise attack and that they now feel that, for the U.S.S.R. to be secure, it must be able to pre-empt the enemy's ability to strike first if he appears about to do so. The author also maintains that "Soviet leaders now believe that the world military balance of power has changed decisively in their favor" (p. 1). He attempts throughout his book to correlate developments in the West and in the struggle for power among the U.S.S.R.'s elite with the evolution of Soviet strategic doctrine.

The last book, Bernard Brodie's Strategy in the Nuclear Age, is the most recent and in many ways also the most comprehensive exposition of the strategic implications of the revolutionary developments in military technology. Mr. Brodie's long work in the field of military affairs is evident in the first section, a description and analysis of the evolution of strategic thought with particular emphasis on the ideas of Guilo Douhet, the foremost exponent of air power. As airpower theories have been so important in shaping American military doctrine, the background this section provides is especially helpful. In the second section, Brodie considers the problems the advent of nuclear weapons and missiles pose for the United States. The problems of defense, deterrence, and limited war, as well as the economic implications of security policy, are explored in detail in this section. The author's policy recommendations include urging greater efforts to protect our strategic retaliatory force (as the United States has renounced preventive war, it must have a second-strike capability) and population and greater efforts to achieve a more diversified military establishment with increased limited war capabilities. He feels that it is important to stress that limited wars must be fought with severe restraints on the means employed and that objectives are indeed limited but primarily because unrestricted war with modern weapons would be intolerable (pp. $312 \mathrm{ff}$.). The book is marked by a sense of political realism and a sensitivity to the profound moral issues involved.

\section{III}

The limits of our knowledge in the field of security policy are great. Predictions about the future course of war have always been hazardous and have often proved woefully wrong. They are even more hazardous today when it is necessary to take into account the as yet only partially revealed revolution in military technology. The secretiveness of the Soviet regime is a further complication.

We actually know very little about the new weapons, yet such knowledge is vitally necessary for any number of crucial decisions; for instance, whether or not we favor the use of nuclear weapons in tactical situations. Kissinger argues for the tactical use of nuclear weapons, claiming that they would favor the technologically superior West and that, if mobile, self-contained units utilized such weapons with appropriate tactics, it would not involve intolerable destruction (pp. $174 \mathrm{ff}$.). Present United States policy seems to be based on these conclusions. Brodie, on the other hand, questions whether using nuclear weapons in tactical situations would be to the West's advantage and doubts that massive destruction could be avoided (pp. $319 \mathrm{ff}$.). He wonders whether insistence on using nuclear weapons may not deter some states from requesting American assistance in the event of an attack or weaken the United States resolve to intervene. Partly, the question of 
the use of nuclear weapons in tactical situations depends upon assumptions about human conduct-would American and Soviet elites during war agree to distinguish between types of nuclear weapons and to limitations on their use? Convincing evidence unfortunately can be presented on both sides. But the issue also hinges on knowledge of the effects of nuclear weapons. One wishes some of the books under consideration contained more data in this area (Brodie's study presents the greatest amount of technical information). Security restrictions, however necessary, have no doubt been partially responsible for the failure to describe in detail the characteristics of new weapons; authors are forbidden to reveal some things and probably do not reveal all that they could because of the inhibitions these restrictions create. More data clearly need to be made available. The Joint Committee on Atomic Energy is to be applauded for its recent efforts in this direction. ${ }^{2}$ It is to be hoped that they will continue. But greater use also needs to be made of the available data. ${ }^{3}$

Nor is weapons technology the only area of ignorance and uncertainty. Dinerstein's thesis that the Soviet Union has adopted a pre-emptive strike policy, if true, would have profound implications. Yet our ability to test this conclusion is extremely limited.

2 See particularly Biological and Environmental Effects of Nuclear War (Washington, D.C.: Government Printing Office, 1959).

3 The best general description of nuclear weapons is The Effects of Nuclear Weapons, edited by Samuel Glasstone, prepared by the Armed Forces Special Weapons Project, and published by the Atomic Energy Commission (Washington, D.C.: Government Printing Office, June, 1957). Mr. Brodie makes frequent use of this. Although it was not available when several of the other studies were prepared, an earlier version published in 1950 was, and there were numerous other public sources.
Dinerstein's most conclusive evidence comes from an article by Marshal of the Tank Troops P. A. Rotmistrov in the Soviet periodical Military Thought (Voennaia mysl') -an authoritative, limited-circulation General Staff organ. Giving this article such great emphasis involves the assumption, which Dinerstein makes (p. 189), that it necessarily represents official policy. United States military officers have also argued that the capability to strike pre-emptive blows is necessary. Admittedly, the degree of central direction differs in the United States and the Soviet Union, but how much can be assumed in each case? The problem is further complicated as few if any scholars outside government have access to Military Thought, and the one other author who does, Garthoff, reaches different conclusions (pp. $84 \mathrm{ff}$.). This is but one of several differences between the two writers. For example, Garthoff thinks that the Soviet elite regards the ballistic missile as "the logical and best weapons system for the mission of deterrence" (p. 231), while Dinerstein thinks that Russian leaders "value the deterrent power of the ICBM, but consider it mainly a weapon of surprise" (p. 229). This writer tends to accept Garthoff's conclusions; they seem more balanced, but they are also more comfortable for the United States. In reality, Soviet intentions are extremely obscure to us. The limits of our knowledge about Soviet capabilities should also be emphasized. The current discussion of the "missile gap" appears to be based mainly on extrapolations of the U.S.S.R.'s estimated capacity for production.

In view of the vast areas of ignorance in the field of security policy, criticisms of past events and recommendations for future courses of action should be extremely cautious. There are, it is true, great pressures in the opposite direction. The policy questions which have been and are to be de- 
cided are of vital importance, bound to generate heat and emotion. In the policy debate, recommendations not forcefully stated risk being overlooked. The very absence of information creates pressures to publish as quickly as possible. Still, it does not seem completely accurate to say, as Osgood does, that Franklin D. Roosevelt's strategy in World War II was that of "pursuing victory in a political vacuum" (p. 116). The historical realities were somewhat more complex, as Osgood himself indicates. Nor does this writer completely agree with Kissinger's estimate of the effects of the development of a doctrine of limited war. While such a doctrine might have been useful, as Kissinger claims, during the Czechoslovakian coup, the Korean War, and the Indochinese and Hungarian crises (if, indeed, we did not have one), it could not have provided a clear guide for action; there were also important value questions at stake in each of these issues. Admittedly, there is a close relationship between doctrinal development and value choices-the risks you are willing to take depend partially on your assessment of what they are and of the possible gains. But value choices were independent elements in each case and will be so in similar instances in the future; they should not be overlooked by emphasis on doctrine. The price Americans are willing to pay for certain anticipated benefits is rightly or wrongly probably fixed within relatively narrow limits, at least in the short range.

These, however, are minor criticisms. The books reviewed all contribute significantly to the fund of available information and analysis. One of the striking features of these works is the uniformity of their policy recommendations. All urge the development of greater protection for our strategic retaliatory forces and increased limited-war capabilities. It would be useful if some future research would explore the practical implications of these recommendations, particularly the latter, as the action needed to implement the former is relatively clear. The places where limited war is likely are fairly few: Korea, the Taiwan Strait, Southeast Asia, and certain areas of the Near and Middle East. Imaginative studies of how limited war could be conducted in these locations would usefully supplement the theory, which is now well established.

Another fruitful area for future research concerns the reciprocal image each superpower has of the others' security policy. There is no analytical attempt to establish correlations between American strategy and detailed developments in Soviet policy. Dinerstein provides some information on the opposite situation in his analysis of the Soviet response to John Foster Dulles' “massive retaliation" speech (pp. $105 \mathrm{ff}$.), and Garthoff describes the Soviet military elite's image of the United States military establishment and plans (chap. vi). Significantly, he has detected no awareness of the Western objective of deterrence (p. 132). But more work in this area might enhance our ability rationally to determine future policy. Estimates must be made about Soviet reactions. This can be done on the basis of logical inference (see Brodie's excellent discussion of the implications of establishing intermediate-range ballistic missile bases in NATO countries [pp. $342 \mathrm{ff}$.]), but it would be better if a greater body of analytical data were available.* Still another area where future research might prove useful is in the field of disarmament. In the past there has been a rather wide gap between

4 Thomas C. Schelling has provided a useful theoretical framework for such work. See his "Bargaining, Communication, and Limited War" and "The Strategy of Conflict," Journal of Conflict Resolution, I, No. 1 (March, 1957), 19-36, and II, No. 3 (September, 1958), 20364. 
those interested in disarmament and those intcrested in security policy; a joining together might be productive. Even if it were not, few separations could be as unfortunate.

\section{IV}

In view of the uniformity of the recommendations advanced in these studies, the fact that they have apparently had so little impact on United States security policy is surprising. In the years since the first of these books appeared, our limited-war capability appears to have declined, and little visibly has been done to protect our strategic retaliatory force. Despite the universal criticism of the "massive retaliation" policy, United States military forces remain structured in this mold.

Perhaps the problems have been oversimplified, or perhaps more concrete recommendations are needed. It may be that scholars in this field, like divisional commanders, have been overly concerned with their own sectors. In the real world security needs must be balanced against others. The chief rationale Dulles offered for the "massive retaliation" policy was after all an economic one. In light of this it is regrettable that only Brodie analyzes the economic problems in detail (chap. x). Probably the most important factor, however, is public apathy. But this too must be explained. Is it as Philip Wylie suggested in an essay reprinted in the Furniss volume that Americans are psychologically incapable of facing the dangers of the nuclear age, or is Osgood correct in arguing that Americans would respond adequately if there were proper leadership?

Whatever explanation one chooses, it is clear that the massive-retaliation posture is probably more congenial to the traditional American attitude of "going it alone" than the recommended alternatives. With this traditional attitude, it is probably more remarkable that the United States has taken the military action it has in the years since the second World War than that it has not done more. And the contrast of our present military capabilities with those of 1939 is certainly greater than with the recommended alternatives. The transition in two decades has been astounding. The new academic interest in security policy is a part of this, and, even acknowledging the current gap between recommendation and policy, scholarship has played an important role in the transition. Whether this transition has gone far enough with sufficient speed, only history will determine. Meanwhile the more scholarship in this area the better. It cannot help but stimulate at least some action, and, the more information and analysis available, the greater our ability to act rationally in this field of rapid change and great danger.

\section{REFERENCES}

1. Brodie, Bernard. Strategy in the Missile Age. Princeton, N.J.: Princeton University Press, 1959.

2. Dinenstein, Herbert S. War and the Soviet Union: The Revolution in Soviet Military and Political Thinking. New York: Frederick A. Praeger, 1958.

3. Funniss, Edgar S., JR. American Military Policy: Strategic Aspects of World Political Geography. New York: Reinhart \& Co., 1957.

4. Garthoff, Raymond L. Soviet Strategy in the Nuclear Age. New York: Frederick A. Praeger, 1958.

5. Kaufmann, William W. (ed). Military Policy and National Security. Princeton, N.J.: Princeton University Press, 1956.

6. Kissinger, Henry A. Nuclear Weapons and Foreign Policy. New York: Harper \& Bros., 1957.

7. Osgood, Robert EndicotT. Limited War: The Challenge to American Security. Chicago: University of Chicago Press, 1957. 